\title{
Sustainable competitive innovative development and economic security of enterprises under unstable conditions: mutual dependency and influence
}

\author{
Ievgeniia Mishchuk ${ }^{1, *}$,Olena Zinchenko ${ }^{2}$, and Maryna Adamenko ${ }^{2}$ \\ ${ }^{1}$ Kryvyi Rih National University, Department of Accounting, Taxation, Public Management and Administration, Kryvyi Rih, Ukraine \\ ${ }^{2}$ Kryvyi Rih National University, Department of Finance of Business Entities and Innovative Development, Kryvyi Rih, Ukraine
}

\begin{abstract}
The paper reveals interrelations between the concepts "economic security", "economic sustainability", "development" and "competitiveness" of an enterprise. Based on their consideration, the paper enhances theoretical and methodological principles of establishing competitive innovation development and economic security of an enterprise. Unlike the existing ones, these principles provide for not only alternativeness but also equal significance when choosing between achievement of high levels of competitiveness, development and economic security. Application of the elaborated suggestions enables more objective formation of the policy of management of an enterprise's innovation development under unstable conditions considering the industrial field and the market position of the enterprise. It is proven that essential elements of enterprises' sustainable development include innovative activity, production provision, export of science-intensive products and development of high technology services, this providing for efficient levels of enterprises' economic security and competitiveness. Under conditions of uncertainty, there are some basic functions of an enterprise aimed at enhancing its competitiveness and economic security including the following: achieving the optimal level of an enterprise's resulting indicators and efficient "income-risk" ratio, innovative activity, ensuring the quality of an enterprise's intellectual capital, environmental safety and meeting required social standards.
\end{abstract}

\section{Introduction}

\subsection{Problem statement and its topicality substantiation}

Establishment of efficient levels of an enterprise's economic security is an essential element of enterprise management as a whole under current unstable macroeconomic conditions. Management of economic security is becoming a priority along with enterprises' competitiveness and financial stability and forms the foundation for their stable innovative development. The basic stage of forming an enterprise's stable economic development involves setting up an efficient permanently functioning system that includes management of competitiveness, economic security, economic sustainability, and innovation and investment attractiveness. Considering this, there are some unsolved problems concerning determination of these basic definitions and their interrelation.

\subsection{Analysis of the latest researches and publications}

A lot of scholars are engaged in solving the problems of an enterprise's sustainable development, its economic security and competitiveness. [1-3, 9, 10, 18-35] deal with some issues of forming, controlling and assessing levels of economic security.

Competitiveness, its types and specific features, methods of its assessment and forecasting as well as scientific approaches to determining interrelation between economic security and competitiveness are under detailed consideration in [4-8, 11-17, 36, 38, 42-44]. It should be noted that foreign researches mostly deal with issues of competitive intelligence and provision of competitiveness of enterprises [45-47]. [39-44] also touch upon the issues of sustainable development on all economic levels including sustainable innovative development. At that, connection of innovations with the level of economic security of enterprises remains unstudied. Analysis of foreign researches into economic security show that there are two most widely spread conceptions - the AngloSaxon and the Asian ones. The former focuses on economic security of households and an individual and is actively popularized in the United States of America [48; 49]. The latter is based on the macroeconomic approach to provision of national economic security. Representatives of some Eastern European schools of thought are among the followers of this conception [50]. Since the 1990s, the third conception has been developing at a rapid rate. It focuses on actualization of economic

* Corresponding author: tdutybz.077@gmail.com 
security of enterprises considering macroeconomic factors. Its fast development started in post-Soviet countries $[50 ; 51]$ which is most probably conditioned by their instable economies resulted in a great number of bankruptcies. Thus, there are some issues left unsolved concerning conditions, under which economic security, competitiveness, sustainability and development influence one another and become identical under unstable economic conditions. For this reason, investigations into conditions determining availability and direction of interrelation between economic security and the mentioned categories are gaining topicality.

\section{Results}

Let us consider interrelation between economic security and competitiveness of an enterprise. The conducted analysis of available scientific investigations into this issue enables the following three directions (Fig. 1).

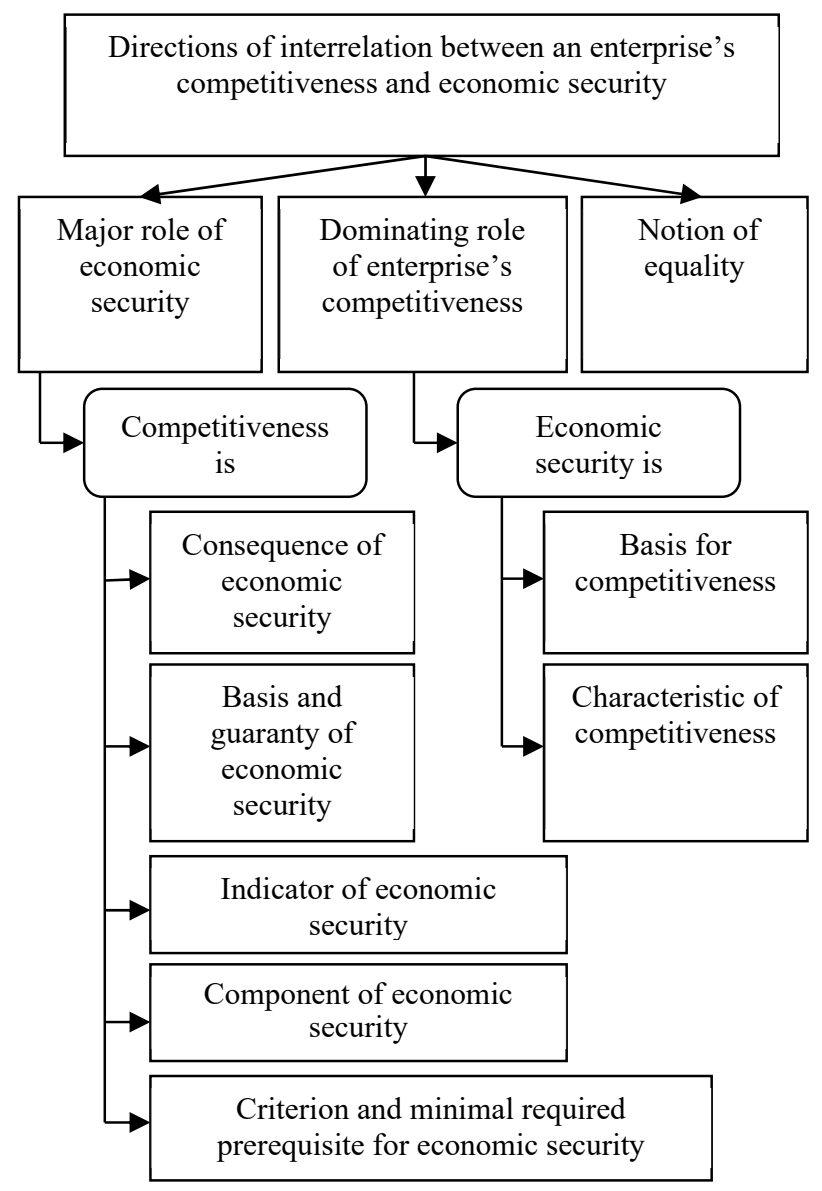

Fig. 1. Directions of interrelation in the conceptual pair "competitiveness-economic security".

In the first direction of investigations, economic security plays a major role. Meanwhile, the content of the secondary role of competitiveness varies.

In particular, the monograph authors [1] consider the difference of notions under study as time characteristics because competitiveness is associated with short-term prospects, while economic security is characterized by an enterprise's ability to function in an efficient and secure manner both at present and in future in accordance with its mission and goals conformed with stages of its life cycle. Within the first approach, the scholars define competitiveness as a notion of secondary importance in terms of economic security and consider it as:

- a consequence of economic security. In O. M. Kuzmenko's opinion, competitiveness is a direct consequence of an enterprise's strong economic security, which is "one of the essential indicators of a stable market position and enables maintaining it for some period of time" (Here and after the translation is ours). The researcher also thinks that interrelation between an enterprise's economic security and its competitiveness is direct and linear, i.e. high competitiveness is a guarantee of its strong economic security (or perception of the latter in such a way) [3];

- the basis and guarantee of economic security. This idea is expressed by K. A. Svekla and I. O. Kuznetsova who indicate that an enterprise's competitiveness is the basis for enhancing economic security and a guarantee of its strong formation enabling an enterprise to preserve its stable market positions [4]. The researchers highlight the potential of successful economic security to enhance business sustainability and competitiveness as a whole [4];

- an indicator of economic security. N. M. Pylypenko describes high competitiveness as an indicator of economic security [5]. According to the Academic Explanatory Dictionary, an indicator is the reason for and a driving force of a process that determines its character or its individual constraints [6].

- a component of economic security. O. O. Falchenko and N. B. Tokar define competitiveness as a component of economic security, which characterizes the degree of conformity of internal potentials of an enterprise's development with its external ones generated by the market environment [7];

- a criterion and a minimal required prerequisite for economic security. A. A. Sadiekov and T. B. Khlevytska consider competitiveness a criterion and a minimal required prerequisite of an enterprise's economic security that enhances its sustainable development [8].

According to M. V. Chorna, provision of an enterprise's economic security should be aimed at achieving basic target indicators of its activity including the required level of competitiveness and stable functioning of an economic entity; facilitation of owners' (shareholders') wellbeing, an enterprise's advance; an ability to survive, i.e. provision of sustainability and accomplishment of economic potential targets; harmonization of social and economic interests [9]. Z. Shershniova investigates into adaptability as an enterprise's competitive advantage and defines it as a result of an enterprise's efficient activity with a created and efficient economic security system [10].

According to the second approach, competitiveness plays a dominating role in the "economic securitycompetitiveness" conceptual pair. As L. M. Khrystenko and A. I. Mykhailichenko think, the dominating role of competitiveness goes without saying, while economic security is its obligatory foundation [11]. I. H. Rzaiev considers competitiveness within the framework of an enterprise's economic security, which is only a 
characteristic of an enterprise's competitive level that guarantees relevant efficiency of an economic entity's functioning that conditions economic security on the economic field level, facilitates indicators of assets, expenditures and financial results [12]. It should be noted that in practice, in Japan, in particular, there is a government strategy of enhancing competitiveness of an economic field as a whole on the world markets, which provides for seven basic strategies of its implementation, development of business economic security being the fifth one [13]. According to the third approach, interrelation of concepts "economic security-competitiveness" is mutually conditioned and neither of them is considered prevailing or secondary. As O. M. Tkachenko indicates, to provide economic security, it is expedient to solve the problem of competitiveness and, vice versa, to achieve high competitiveness, it is necessary to enhance its economic security [14].

It is also worth noting that there are cases when an author or authors express contradictory ideas within the same paper. For instance:

- L. M. Khrystenko and A. I. Mykhailichenko indicate that except for the above-mentioned, an enterprise that does not ensure its own economic security is unable to use its competitive advantages and is heading for their loss [11];

- O. M. Tkachenko identifies an enterprise's competitiveness as the basis of its economic security and a guarantee of its strong development that enables an enterprise to maintain its stable market positions [14].

Use of the concept "development" in the definitions of both economic security and competitiveness of the enterprise is another block of investigations (Fig. 2).

Concept "development": in definitions of conceptual pair "competitiveness - economic security"

\begin{tabular}{c} 
Competitiveness \\
$\begin{array}{c}\text { Relative category } \\
\text { describing difference } \\
\text { of enterprise } \\
\text { development process } \\
\text { from competitor }\end{array}$ \\
\hline $\begin{array}{c}\text { Development } \\
\text { mechanism }\end{array}$
\end{tabular}

Fig. 2. The general concept "development" in definitions of the conceptual pair: competitiveness - economic security of an enterprise.

The principal difference between the definitions of competitiveness of an enterprise and those of economic security contrasted to them in Fig. 2 lies in the fact that the former mostly focus on comparison of the enterprise with its competitor while in the definitions of economic security enterprise development is considered separately from other economic entities and, moreover, economic security itself is identified with competitiveness. The analyzed definition treated in terms of enterprise development enable concluding that essentiality of the concept of economic security of an enterprise is deeper than its competitiveness. Besides, analysis of the literature, including [18-20], enables differentiating this trend in connection with the concepts of development and economic security where economic security is the same as development, a state of development or an ability to develop. We suggest the name "complete identification"

In most scientific works that consider the concept "enterprise development", the latter results from a certain condition of an enterprise or efficient use of its resources (Fig. 3).

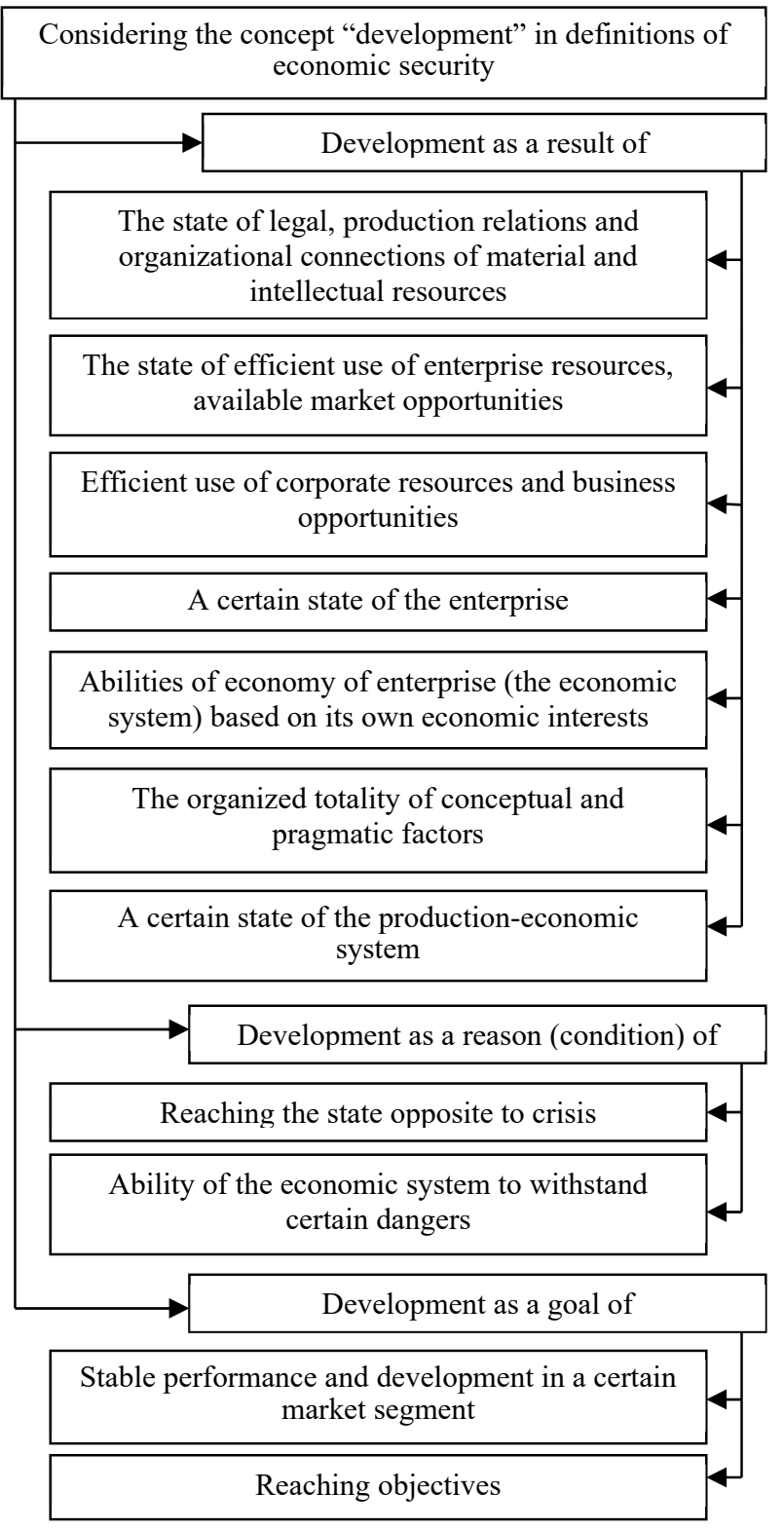

Fig. 3. Development roles in various definitions of economic security of the enterprise).

Let us consider the work by Ye. O. Didenko where the process of managing economic security is identified with the strategy of secure development of an enterprise which is a complex program of actions determining priority trends of economic activities when threats to the enterprise emerge as well as necessary resources to prevent them or minimize their impacts [32]. 
However, the majority of researchers dealing with economic security of an enterprise assign its development to objectives of the security provision even if they do not mention this in the definition. For instance, according to N. P. Sysolina, in management of economic security there are singled out contours of operating management characterized just as resistance to already emerged threats; tactical management characterized by the ability of adaptation and strategic management noted for by the ability of continuous development [33].

There is no consensus among the researchers on which of the concepts under analysis is primary and which is secondary; whether development is the objective of economic security or the enterprise can only develop in conditions of economic security. The only common thing is that most researchers recognize the relation between the concepts and call it the cause-and-effect relation. Several works attempt to settle these problems. However, analysis of these works shows contradiction and ambiguity of the answers. The critical review of specialized literature enables us to identify bipolarity of scholars' views on the relation between the concepts "enterprise development" and "economic security" - some scholars consider it linear, others call it direct [21-33]. On the contrary, in [34] (with the reference to M. O. Dzhaman and G. O. Goncharova), the categories "security" and "development" are called equal and independent. Nevertheless, we believe that interinfluence of development and security does not allow stating principal absence of relations between them even in case of the equal approach. Absence of relations may occur in the short-term period. The conducted research enables systematizing current ideas of relations between development and economic security into four directions (Fig. 4).

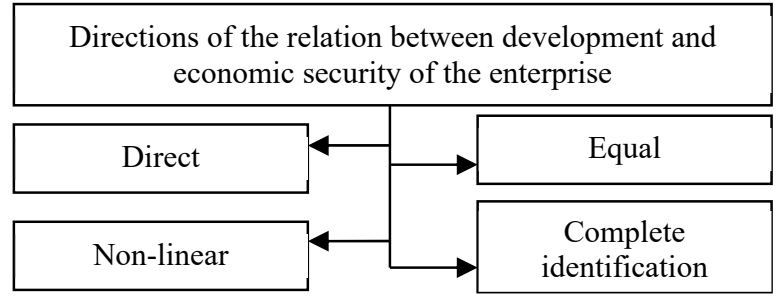

Fig. 4. Directions of the relation between development and economic security.

We believe that all the four directions are not mutually exclusive. On the contrary, all scholars are right: relations between economic security and development may be direct, non-linear, complete identification and equal under certain goals, conditions and circumstances. Comparison of the essence of the concept of economic sustainability with that of economic security elicits issues for discussion. Thus, in [35] the definitions of enterprise economic security contain features that do not have analogues in the term "enterprise economic sustainability". Along with that, there exists an opposite situation when the definitions of "enterprise economic security" contain specific characteristics, e.g. the concept "equilibrium" ("equilibrium state"). For instance, Yu. A. Simekh characterizes economic sustainability of an enterprise as its potential to return to the state of equilibrium in which it possesses positive dynamics of performance or stay within the established boundaries [36]. However, some scholars find this question debatable. Thus, according to the systems theory, equilibrium is a separate case of system sustainability which indicates inexpediency of identifying it with equilibrium or the ability to return to it [37]. So, analysis of scientific literature enables us to assert that between the concepts under study there are more similarities than differences. On the basis of the conducted research, we suggest common approaches to understanding the essence of the concepts "enterprise economic security" and "enterprise economic sustainability" underlain by various classification features: static, dynamic (process); resource-functional, adaptive-developmental, supportive goal-oriented; complex (mixed). At that, different approaches to enterprise economic security are harmonization, guarantee and protective, those to enterprise economic security are equilibrium (which is debatable) and renewable (reproducing). We believe that enterprise economic sustainability is of triple nature as is economic security. It is characterized simultaneously as a state, a process and a resource of an enterprise. At that, having common resource provision and businessprocesses of provision and support, economic security may be identical to economic sustainability of the enterprise. So, four possible situations can be elicited (Fig. 5).

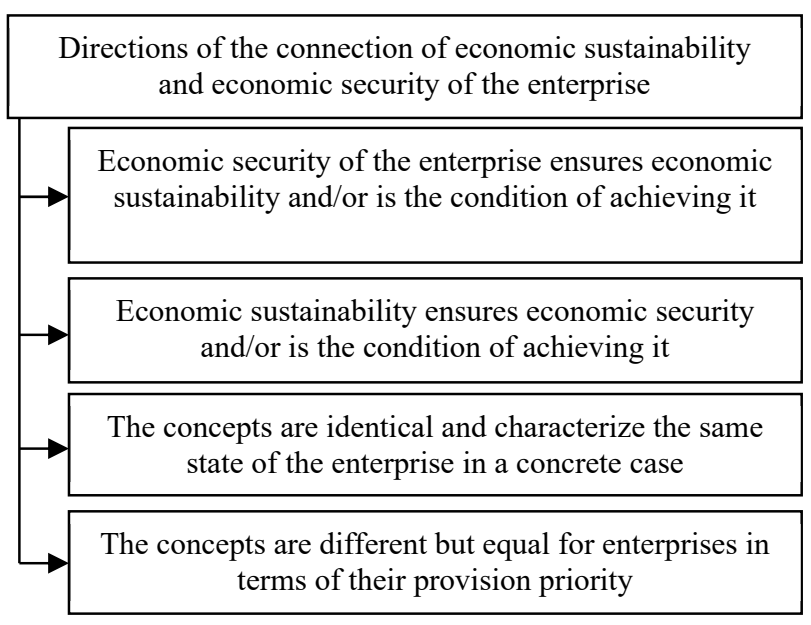

Fig. 5. Directions of the connection of economic sustainability and economic security of the enterprise.

Enterprise being in one of the mentioned situations depends on the set goals, performance conditions, multivariance of internal and external environments and availability of resources (Fig. 6).

Economic instability is an important complicating exogenous factor, the impact of which must first be offset in the process of managing a competitive innovative development of the enterprise. The red line in most scientists' researches defines component aspects of such leveling.

At the first stage, it is necessary to determine directions and vectors of influence of such conditions on the basic financial and economic results of an enterprise 
(its market capitalization, capitalization rates, absolute and relative indicators of economic efficiency, owners' income levels, quality of profit, etc.).

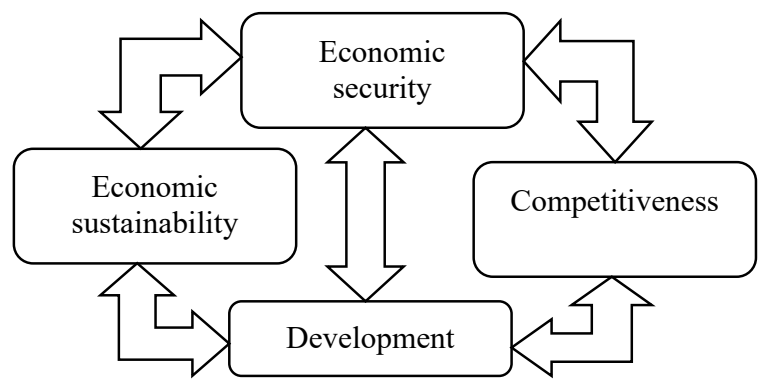

Fig. 6. Relation of economic security with key concepts: competitiveness, development, sustainability.

The second stage of counteracting such an impact is to calculate general, local and partial indicators of assessment and analysis of the economic activity of the enterprise. In doing so, both the classical methodological approaches of such analysis and the specific ones (for example, methods of measuring the probability of bankruptcy) are used.

The third stage involves development of a system of organizational and economic steps to ensure economic security under corresponding conditions. This kind of system represents a well-run mechanism comprising such basic components as updating the system goals, setting aims and objectives, determining principal tasks of leveling uncertainty of the environment, singling out subjects and objects of the mechanism, establishing interrelations between the subjects and objects, developing managerial measures and priority of functional stages, developing proposals about controlling and coordinating managerial processes.

It should be noted that focus on innovation is an important element of sustainable development of the enterprise. For instance, at enterprises of developed countries sustainable development is ensured at the expense of manufacturing and export of science-intensive products. The countries are gradually closing down purely industrial production and developing high-tech intellectual services. One can state that, unlike in Ukraine, development of enterprises in these countries is aimed at increasing rates of the scientific and technological progress, building up intellectual capital. All the mentioned is a guarantee of establishing the appropriate level of economic security and competitiveness of enterprises. So, sustainable development of enterprises should be based on application of radically new progressive technologies, managerial systems, intellectualization and informatization of production, environmental safety, etc.

Under conditions of uncertainty the following basic functions of the enterprise aimed at ensuring competitiveness and long-term economic security can be singled out:

a) achievement of an optimal level of resulting indicators of enterprise performance (the increased market value of the enterprise, increased owners' incomes, increased economic efficiency); b) achievement of an optimal "income-risk" ratio;

c) innovativeness (one of the key functions of the enterprise which enables the enterprise to ensure maintenance of its long-term economic efficiency and competitiveness at each stage of its life cycle through timely and reasonable implementation of innovations);

d) provision of quality of intellectual capital of the enterprise (quality of intellectual capital is closely connected with establishment of the innovation and information level of the enterprise. Increase of the level of intellectual capital quality is ensured through involvement of new knowledge on the basis of qualitative personnel recruiting (especially top-management of the enterprise)); e) provision of continuous environmental safety (environmental protection in conformity with basic requirements of environmental and green economy);

f) maintenance of the required level of social standards of the enterprise, etc.

Continuous monitoring of performing the abovementioned functions is a prerequisite for reaching the optimal level of economic security of the enterprise. In addition, applying the suggested algorithm of leveling the instability, it is required to determine possible increase of the level of sustainable competitive innovation-oriented development.

\section{Conclusions}

Thus, in our opinion, correlation of the concepts of economic security - competitiveness depends on the enterprise capacity, specific character of functioning (necessity of licenses, permits, unique production, etc.) and an industrial field. For instance, small enterprises work in conditions close to perfect competition and, therefore, their competitiveness is top-priority to them as it underlies their economic security. Mining and metallurgical enterprises work in conditions of oligopoly and that is why the interrelations here are objective. For enterprises-monopolists, competitiveness plays a smaller part. Thus, sustainable competitive innovative development and economic security of enterprises under unstable conditions is an important task for topmanagement activities. Scientific novelty of the present paper consists in enhancement of theoretical and methodological principles of forming competitive innovation development and economic security of enterprises that will facilitate better management under conditions of uncertainty and instability. To achieve this, the article determines interrelations and interdependencies of corresponding economic definitions, suggests methodological approaches to leveling the negative influence of uncertainty and instability and emphasizes the necessity of innovative development.

\section{References}

1. T. Vasylsiv, V. Voloshyn, O. Boykevych, V. Karkavchu, Financial and economic security of Ukrainian enterprises: strategy and mechanisms for ensuring (Lviv, 2012) 
2. O. Rudkovskyi, Bulletin of the National Transport University 29(2), 93-99 (2014)

3. O. Kuzjmenko, Economic security of the enterprise: connection with other categories and concepts (2014),

http://thesis.at.ua/publ/bezpekoznavstvo teorija ta praktika/kuzmenko_o_m_ekonomichna_bezpeka_pi dpriemstva_zv_39_jazok_z_inshimi_kategorijami_t a_ponjattjami/4-1-0-172. Accessed 20 Dec 2019

4. K. Svekla, I. Kuznetsova, Competitiveness and economic security of the enterprise. Paper presented at the International Scientific and Practical Conference "Economics: Realities of Time and Prospect", Odessa National Polytechnic University, Odessa, 20-21 February 2014

5. N. Pilipenko, Competitiveness as an integral part of ensuring the economic security of the enterprise. Paper presented at the international scientific internet conference "The Status and Prospects of Development of Accounting and Analytical Support for Entrepreneurship Management in the Conditions of European Integration Processes", KNTEU, Chernivtsi, 26-27 November 2015

6. Dictionary of the Ukrainian language (1980), http://sum.in.ua/p/11/326/2. Accessed 20 Dec 2019

7. O. Falchenko. N. Tokar, Bulletin of the National Technical University "KhPI": Technical progress and production efficiency 67(1040), 156-158 (2013)

8. A. Sadekov, T Khlevytska, Theoretical and applied issues of economics 24, 148-155 (2011)

9. M. Chorna, I. Piriatinska, Efficient economy 10 (2012),

http://www.economy.nayka.com.ua/?op=1\&z=1477 3. Accessed 20 Dec 2019

10. Z. Shershneva, Strategic management. (Kyiv, 2004)

11. M. Khrystenko, A. Mykhajlichenko, Communication of competitiveness and economic security of the enterprise

(2014), http://thesis.at.ua/publ/2014_r_bezpekoznavstvo_teo rija_ta_praktika_15_03_15_04/khristenko_1_m_mik hajlichenko_a_i_zv_jazok_konkurentospromozhnost i_ta_ekonomichnoji_bezpeki_pidpriemstva/10-1-0326. Accessed 20 Dec 2019

12. G. Rzaev, Collection of scientific works of Lutsk NTU: Series "Economics and Management" 7(26), 3, 67-77 (2010)

13. I. Anishchenko, Yu. Pynchuk, Economy and the state 10, 29-33 (2005)

14. O. Tkachenko, Formation of market relations in Ukraine 4(167), 157-162 (2015)

15. M. Ermolov, How to sell goods on the foreign market (1990), pp. 228-241

16. Yu. Ivanov, N. Tyshchenko, N. Drobytko, O. Abramov, Enterprise competitiveness: assessment, diagnostics, strategy (Kharkiv, 2004)

17. G. Khamel, K. Prakhalad, Competing for the future, vol. 12 (Moscow, 2002)
18. I. Moiseienko, Bulletin of the Lviv State University of Internal Affairs: the series is economical 1, 140147 (2011)

19. I. Otenko, A. Yaroshenko, Uzhgorod University Scientific Bulletin. Economy series 22, 2, 43-48 (2007)

20. V. Heiets, M. Kizim, T. Klebanova, O. Chernyak, Modeling of economic security: state, region, enterprise (Kharkiv, 2006)

21. V. Muntyan, Economic security of Ukraine (Kyiv, 1999)

22. A. Melykhov, E. Kamishnikova, Bulletin of Pryazovskyi State Technical University 19, 316-319 (2009)

23. Z. Zhyvko, Economic security of the enterprise: essence, mechanisms of providing, management (Lviv, 2012)

24. R. Fedorenko, Resource management system as a basis for ensuring economic security. Paper presented at the Research Practice Conference "Non-state system of business security as a subject of national security of Ukraine", Kyiv, 2003

25. P. Kolpakov, Economics and management of innovative technologies (2013), http://ekonomika.snauka.ru/2013/01/1567. Accessed 20 Dec 2019

26. Yu. Lysenko, S. Mischenko, R. Rudenskyi, Economic Security Management Mechanisms (Donetsk, 2002)

27. P. Popovich, Bulletin of Ternopil Academy of National Economy 2, 93-96 (2002)

28. M. Voinarenko, O. Yaremenko, Ekonomist 12, 6063 (2008)

29. N. Gychova, Economics: problems of theory and practice 247(IV), 634-636 (2004)

30. D. Matsekha, Socio-Economic Research Bulletin 1(48), 128-133 (2013)

31. V. Tambovtsev, Bulletin of Moscow State University: Series 6 Economics 3, 3-24 (1995)

32. I. Dydenko. Formation of market relations in Ukraine 5(168), 35-40 (2015)

33. N. Sysolyna, Economic security of the enterprise (Kyrovograd, 2014)

34. S. Fylypova, Economic security of enterprises of the real sector of economy in the conditions of valueoriented management (Odesa, 2015)

35. I. Mishchuk, Bulletin of Zhytomyr State Technological University 1 (83), 83-89 (2018)

36. Yu. Symekh, Bulletin of the International Slavyanskyi University: Series Economics 1, 12-16 (2007)

37. R. Feshchur, Kh. Baranyvska. Bulletin of the National University "Lviv Polytechnic" 684, 284290 (2010)

38. V. Nusinov, Ie. Mishchuk, Ya. Izmaylov, Baltic Journal of Economic Studies 5(4), 160-170 (2019) 
39. R. Gayrbekova, F. Abitaeva, Science and World 32(2-4), 17-19 (2016)

40. T. Gviniashvili, T. Grynko, Economic Annals-XXI 165(5-6), 80-83 (2017)

41. F. Ezzi, A. Jarboui, Journal of Economics, Finance and Administrative Science 40(21), 14-24 (2016)

42. S. Terjesen, C. Patel, Journal of Management. Working 43(5), 1421-1446 (2017)

43. V. Levchenko, A. Boyko, T. Savchenko, V. Bozhenko, Yu. Humenna, R. Pilin, Marketing and Management of Innovations 4, 364-372 (2019)

44. D. Zatonatskiy, Marketing and Management of Innovations 1, 294-301 (2019)

45. J. Calof, Journal of Intelligence Studies in Business 6(1), 48-58 (2016)

46. D. Toit, Journal of Intelligence Studies in Business 2 , 14-21 (2015)

47. G. Giannopoulos, R. Filippini, M. Schimmer, Risk assessment methodologies for critical infrastructure protection: part I (Luxembourg, 2012), p. 70

48. Financial Security Program (The Aspen Institute, 2012),

https://www.aspeninstitute.org/programs/financialsecurity-program/. Accessed 5 March 2020

49. B. Ajdari, S. Asgharpour, Human security and development, emphasizing on sustainable development. Procedia Social and Behavioral Sciences 19, 41-46 (2011). doi:10.1016/j.sbspro.2011.05.105

50. R. Tamošiūnienè, C. Munteanu, Current research approaches to economic security. Paper presented at the 1 st international conference on business management, Valencia, Spain, 2-3 July 2015

51. A. Ianioglo, T. Polajeva, Origin and definition of the category of economic security of enterprise. Paper presented at the 9th international scientific conference proceedings "Business and Management 2016”, Vilnius, Lithuania, 12-13 May 2016 